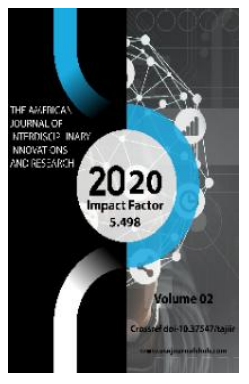

Journal Website: http://usajournalshub.c om/index,php/tajiir

Copyright: Original content from this work may be used under the terms of the creative commons attributes 4.0 licence.

\section{Theme: Forecasts And Results Of The Negative Impact of The Covid-19 (Coronavirus) Pandemic On The World Economy And The Economy Of Uzbekistan}

\author{
Firdavs Urokov Ortikniyozovich \\ Samarkand Institute Of Economics And Service, Employee Of Educational-Methodical \\ Department, Uzbekistan
}

\title{
ABSTRACT
}

This article describes in detail the forecasts of the negative impact of the COVID-19 (coronavirus) pandemic on the world economy and the economy of Uzbekistan. The negative impact of the pandemic of the COVID-19 (coronavirus) on the world economy and the economy of Uzbekistan is also directly reflected in the results of forecasts. Also, the results of the direct impact of the COVID19 pandemic on the world economy, in particular the economy of Uzbekistan, were analyzed, the results of the economies of the countries were compared.

\section{KEYWORDS}

COVID-19, gross demand (AD) and gross supply (AS), economy of world countries, national economy of Uzbekistan, partner countries, attractive consumers, general movement "Saxovat and support", international rating agency "Moody's", project "listening to the citizens of Uzbekistan", Center for World Bank and development strategy, living standards of the population.

\section{INTRODUCTION}

Our analysis shows that the development of small countries, including the economy of Uzbekistan, will cover economic losses in 5 or 6 months, the growth rate of this year's GDP will increase by $1.2-1.5$ percent and next year by 7.0-7.2 percent, says professor Tursin Shodiyev .
As a result of the global spread of the coronovirus pandemic, which appeared at the end of 2019 year in the people's Republic of China's City of Uwan, a global crisis arose. This is different from the world crises in different aspects, and its negative impact on the economy is becoming very strong. Speaking in the economic language, this pandemic is an external "shock" to gross demand (AD) and 
gross supply (AS), macroeconomic stability (external shock), which differs greatly in terms of scale and damage from previous economic crises.

This crisis occurred suddenly in 185 country of the world. It showed a simultaneous impact on gross supply and gross demand. The emerging open global economy and national economies have been in a closed form for several months. Little experience has been accumulated in the World Economic Literature on the identification and mitigation of the negative impact of the coronovirus pandemic on the world and regional economies, and the topic has not been systematically studied. The purpose of this article was to partially study the consequences of the spread of the coronovirus pandemic to global and regional qualifications and to predict the effectiveness of measures aimed at mitigating its consequences in our republic1.
Economy in the period until the coronovirus pandemic

The result of the research shows that until the onset of the coronovirus pandemic, positive silences were observed in the world economy and national economies, signs of sustainable development. Its high rates have been observed in China, Tajikistan, Armenia and Uzbekistan, low rates in the US, UK, Russian Federation, when the pace of economic growth in the world economy in recent years is around 3 percent on average. Gross revenues of the world economy in 2019 amounted to 84.5 trillion US dollars, including 20.6 US dollars (share 24.4 percent), 13.1 (share 15.6\%) of the people's Republic of China, 3.9 (4.6\%) of Germany, 2.8 (3.3\%) of Great Britain, 1.5 (1.9\%) of Russia and South Korea.

\section{(Table 1)}

1-table. The state of the world economy and economic cooperation with Uzbekistan in 2018 


\begin{tabular}{|c|c|c|c|c|}
\hline Countries & $\begin{array}{c}\text { Area,thousand } \\
\text { sq.km }\end{array}$ & $\begin{array}{c}\text { Population } \\
\text { the } \\
\text { number } \\
\text { (mln. man) }\end{array}$ & $\begin{array}{c}\text { GNP } \\
\text { (bln.fertilized) }\end{array}$ & $\begin{array}{l}\text { Population per } \\
\text { capita income } \\
\text { (fertilized ) }\end{array}$ \\
\hline Usa & 9831,6 & 327,2 & 20636,3 & 63080 \\
\hline Great British & 243,6 & 68,5 & 2777,4 & 41770 \\
\hline Germany & 357,6 & 82,9 & 3905,3 & 47090 \\
\hline Russia & 17098,3 & 144,5 & 1501,7 & 10230 \\
\hline China XR & 9562,9 & 1392,7 & 13181,4 & 9460 \\
\hline South Korea & 100,3 & 51,6 & 1580,1 & 30600 \\
\hline Kazakhstan & 2724,9 & 18,3 & 147,6 & 8070 \\
\hline Uzbekistan & 447,4 & 33,0 & 66,5 & 2020 \\
\hline Kyrgyzstan & 200,0 & 6,3 & 7,7 & 1220 \\
\hline Tajikistan & 141,4 & 9,1 & 9,2 & 1010 \\
\hline Turkmenistan & 488,1 & 5,9 & 39,4 & 6740 \\
\hline Belarus & 207,6 & 9,5 & 53,8 & 5670 \\
\hline Armenia & 29,7 & 3,0 & 12,5 & 4230 \\
\hline Turkey & 785,4 & 82,3 & 858,1 & 10420 \\
\hline World on & 132025,2 & 7594,3 & 84478,9 & 11124 \\
\hline
\end{tabular}

of further development of our country in 2017-

President Shavkat Mirziyoyev's address to the 2021, will serve as an

Parliament of the Republic of Uzbekistan in 2020 year 24 January, as well as the so - called "Year of development of Science, Education and digital economy", which is aimed at fulfilling the tasks defined in the strategy of action to implement the five priority directions

The negative impact of the coronovirus pandemic on the global economy and the major economic partner countries of Uzbekistan

In order to mitigate the negative effects of the Global crisis on the socio - economic development of the Republic of Uzbekistan, 
decrees of the president of the Republic of Uzbekistan "on measures in the first place to mitigate the negative impact of the Coronovirus pandemic and the global crisis situations on the economic sectors" and "on additional measures to support the population, economic sectors.

As indicated in the decree, in the fight against the spread of coronavirus infection on a global scale, unprecedented measures are being taken in our republic by restricting the movement of people and stopping the activities of enterprises. The economy of Uzbekistan, which is part of the Global economic system, is also affected by these factors, which in turn requires effective preventive measures to mitigate the negative effects of this situation. It is necessary to pay special attention to the support and stability of dynamically developing sectors of the Republic's economy, such as tourism, transport, pharmaceutical and textile industries.

The figures and their analysis show that countries that have suffered so much from globalisation and integration, bilateral and multilateral economic ties, to the crisis, suffer so much from the coronovirus pandemic. The analysis suggests that while there is a correlation between the share of countries in the world economy and the share of those affected by coronovirusadorlik $(R=0,75)$, the economic losses of countries from the coronovirus pandemic also depend on the share of epidemics. The table below shows how countries ' economic losses and per capita incomes are projected to decline in the negative impact of the coronovirus pandemic.

2-table. The forecast of economic losses in the negative impact of the coronovirus pandemic2 


\begin{tabular}{|c|c|c|c|}
\hline Countries & Total economic loss,bln.\$ & $\begin{array}{c}\text { Each the losses of the } \\
\text { month, billion. } \mathbf{\$}\end{array}$ & $\begin{array}{c}\text { Each to the loss of } \\
\text { population, } \mathbf{\$}\end{array}$ \\
\hline Usa & 619,09 & 51,59075 & 1892,08 \\
\hline Great British & 83,32 & 6,9435 & 1216,38 \\
\hline Germany & 117,16 & 9,76325 & 1413,26 \\
\hline Russia & 45,05 & 3,75425 & 311,77 \\
\hline China XR & 395,44 & 32,9535 & 283,94 \\
\hline South Korea & 47,40 & 3,95025 & 918,66 \\
\hline Kazakhstan & 4,43 & 0,369 & 241,97 \\
\hline Uzbekistan & 2,00 & 0,16625 & 60,45 \\
\hline Kyrgyzstan & 0,23 & 0,01925 & 36,67 \\
\hline Belarus & 1,61 & 0,1345 & 169,89 \\
\hline Armenia & 0,38 & 0,03125 & 125,00 \\
\hline Turkey & 25,74 & 2,14525 & 312,79 \\
\hline The world & 2610,00 & 217,5 & 343,68 \\
\hline
\end{tabular}

If we look at the table data, the per capita decline in population incomes is projected in the US (1892 dol), followed by Germany (1413), Great Britain (1216), South Korea (918dol), Russia (311) and China (284dol). Total loss in the Republic of Uzbekistan amounted to 2.1 billion. It will be in US dollars and about 60 dollars per capita. To compensate for the losses in the incomes of the population, some countries are distributing money. However, the government of the Republic of Uzbekistan makes an alternative decision and through the general movement "support and assistance" enterprises and public organizations conduct charitable events for low-income families.
Participation of enterprises in the general movement of "support and assistance" is not an attempt by the state to reduce the losses of the crisis to entrepreneurs, but an attempt to rectify the situation in which the same gross demand is falling. Because in the period when the gross offer declined, increasing the gross offer by distributing money to the population increases inflation and the population may not see any benefit from it. Participation of enterprises in the general activity brings them profit.

First, the enterprise would have to make advertising costs for the sale of goods or 
services (in the period when the demand for previously collected reserves fell;

* Secondly, the participation of the enterprise in the overall movement of "Saxovat and support " increases the reputation and image of buyers, its population;

* Thirdly, participation in the general movement revitalizes the previously formed chain economic ties between enterprises. Doing business will save money and the costs of marketing from the four, because they will form a group of attractive (consumer loyalty) consumers in the future, etc.the $G$.

\section{Economic recovery and development after the end of the coronovirus pandemic}

During the ongoing crisis, the primary tasks of the national economy are to restore market confidence, reduce the disruptive sector, primarily the affected area of renta relations and develop competitiveness. The effectiveness of the transfer of the national economy from the energy-raw material road to the innovative direction is determined by the level of trust of relations between various social groups of the population, authorities and business. Also, in order to mitigate the effects of the coronovirus pandemic on the competitiveness of enterprises and their economic situation, measures were recommended to reduce production costs, cheapen the cost of products, save transactional costs.

Measures are set out to grant preferential credits to enterprises with financial impairments, to create incentives to repay loans received from the bank, to encourage the reduction in the capacity of energy and other raw materials of products, to introduce local producers into localization programs, to increase the domestic demand for their products. On account of the expansion of production with new products and activities, measures are being implemented to diversify, increase the assortment and quality of products and services, increase the value added capacity in them, expand sales channels and markets, ensure employment, self employment.

These circumstances will serve to the transition of our country to a stable development Troy in the future, restoring the state of our country from the crisis impact at a rapid opportunity to the crisis. In this regard, the scenarios of post-crisis development among other scientists are controversial. Some scientists and specialists predict that the development of future economies will be in Latin L - form ( $L$ - shape), $U$ - form ( $U$ shape) or $V$-form (V-shape). The appearance of these letters represents the shape of the gross proposal curve. In other words, it is said that national economies and the world economy will enter the stage of development into its previous form. Our analysis shows that the development of small countries, including the economy of Uzbekistan, covering economic losses in 5 or 6 months, the growth rate of this year's GDP will be around 1.2-1.5 percent and next year will be up to $7.0-7.2$ percent. The world economy and the economies of developed countries (the United States, Germany, Turkey, China, Russia) develop in a $\mathrm{U}$ - shaped way, in other words, it takes more time (one and a half years) for these economies to recover and develop.

To compensate for the economic losses caused by the coronovirus pandemic for our republic, we think that this year it will take 5 or 6 months, and economic growth in the current year will be around 1,2-1,4 percent, and in the next year the growth rate as the product of the anti-crisis measures will be around 7,0 and

"The coronavirus pandemic is turning into a"black-and - white" and is coming up with even more obvious consequences than the Great Recession of 2008-2009, "said John Lonski, economist at Moody's international rating agency. 
"In contrast to the ongoing crisis, this time the opportunities of the states in the direction of balancing the situation have been limited, " he warned.

The Chinese economy has become much sluggish even without the virus. Last year, its economy grew by 6.1 per cent, which is more than that.

In addition, the transition of the country's economy to a new system, the entry into a trade war with the United States, and the situation in Hong Kong also caused a deepening of the crisis.

The Virus was the first to cause damage to transport, trade, restaurant and hotel business. The fact is that the country stood on the eve of the most boiling season of the year - the celebration of the Chinese New Year.

Production was also in crisis: most of the enterprises and factories were closed, the workers were sitting at home, in quarantine, according to the government decree, it was difficult to deliver the goods to the buyers because the transport was almost not walking.

Toyota and Volkswagen stopped their Chinese conveyors, Starbucks and McDonalds' offices were also closed.

China-one of the most basic countries for the supply of bolts for the production of industrial and consumer goods. Especially on electronics

Vietnam, South Korea, Cambodia, Singapore and Japan have all suffered losses as a result of the banning them from leaving overseas as a group. Because they were separated from Chinese tourists, which flowed on winter holidays.

The interruption of work in industrial enterprises was a huge loss for the countries of Australia and Brazil, which were the main suppliers.
And Europe and the United States were separated from many Chinese tourists and buyers of flashy goods.

The nightmare of the crisis has frightened especially investors. They began to buy shares, oil, metals, began to buy bonds and gold from developed countries.

Oil prices fell sharply, as China-the largest buyer, buying 14 million barrels of oil per day, reduced its consumption by twenty percent3.

Metal products used in industry prices for copper, nickel, aluminum also fell 7 percent due to the virus3.

The Center for Economic Research and reform, together with the World Bank and the Center for development strategy, conducted a study on the socio-economic consequences of COVID-19 .

On the results of the study of the socioeconomic consequences of the COVID-19 conducted within the framework of the project" listening to the citizens of Uzbekistan".

The Center for Economic Research and reforms together with the World Bank and the Center for development strategy conducted a study on the impact of the COVID-19 pandemic on the socio-economic life of citizens of the Republic of Uzbekistan. This study was carried out within the framework of the project" listening to the citizens of Uzbekistan", which aims to assess the welfare of citizens and to study public opinion on the reforms carried out by the Government of Uzbekistan.

For information: the project "listening to the citizens of Uzbekistan" of the World Bank (L2CU) annually studies the socio-economic situation of 1500 households of the Republic of Uzbekistan. Starting in 2019, 21 questionnaires were conducted within the framework of the project. The last survey was conducted on may 21, 2020. 
According to the results of the study, the following were identified4:

\section{In the field of social welfare:}

- Slightly increased employment. The proportion of households with at least one working member decreased by more than 40 percent in April compared to March. In the period from April to May 15 f.the p. increased (from $43 \%$ to $58 \%$ ).

- householdonlarda the number of respondents reported that someone had "lost or failed to work" increased from $1 \%$ in March to $19 \%$ in April.The number of those who lost their jobs in April-may decreased from $19 \%$ to $12 \%$ as a result of the implementation of the program of large-scale measures taken against the crisis.However, almost all respondents believed that the suspension of their activities was temporary.

- The level of poverty can deteriorate. Since the outbreak of the COVID-19 pandemic in April, the proportion of people living below the poverty line has reached $10 \%$ ( $7,4 \%$ in March). This again means that 448 thousand people will be able to get out of the poverty line as a result of a decrease in the standard of living.

- Food consumption is improving. The share of households, which reported a decrease in food consumption, fell from $26 \%$ in April to $23 \%$ in may.

- Receive immediate public assistance. Since the appearance of COVID-19, $9 \%$ of the population has been reported to have received direct government assistance. The largest part of the help ( $89 \%$ ) is given in the form of natural (commodity).

\section{In the field of Education:}

- Despite the fact that all schools were closed in May, almost all school-age children participated in certain educational and educational activities
(97\%). Most of the respondents (69\%) were satisfied with this exercise and $8 \%$ were dissatisfied.

- $87 \%$ of the students determined that the bulk of the training was carried out through educational television programs. For $6 \%$ of the students, mobile learning aids are the basic learning method, while $5 \%$ of the students have learned through assignments given by the tutor or teacher.

- Householdonlarda high availability of television and television programmes (more than 91\%) through this system partially understand that training is on a large scaletiradi. $70 \%$ of households have smartphones and about half of them are connected to the mobile internet. $17,5 \%$ of respondents have a personal computer or laptop, $8 \%$ are connected to the apartment's wired internet.

\section{Services and household expenses:}

- Since the outbreak of the COVID-19 epidemic began, $6 \%$ of households have reported that ida citizens need medical care.

- Household expenses are different. 55\% of respondents reported a change in costs. According to these changes, near $60 \%$ of respondents reported an increase in costs (on average and significantly) compared to the previous 30 days, as well as they had higher costs than the average earnings. Approximately $40 \%$ reported a reduction in costs (23\% reported an "average" reduction and $77 \%$ reported "significant"). Most of those who reported a reduction in costs were lowincome respondents.

- Improved product shortage problems. Approximately $6 \%$ of respondents in May reported that certain goods were not sold in their territories, $16 \%$ in April. These products include food products, especially bread and flour. In May, the 
situation significantly improved, so that the number of disruptions in food supply decreased by about 6\%. Those who reported that the drugs and masks were not on sale fell for a while in may, when they accounted for $5 \%$ in April.

\section{In the field of living standards:}

- $\quad 79 \%$ of those surveyed reported a change in lifestyle with the prevalence of COVID19. The most common changes in people's behavior are: wearing a mask (95\%), shortening of family and friends ' visits (84\%), frequent washing of hands (83 \%), handshake / hugging / greeting ( $82 \%)$, social distance $(72 \%)$, exit from outof-work homes (51\%), isolation / quarantine (19\%). The number of respondents who reported that they had recently participated in mass events in May is zero.

Social attitude towards the effectiveness of reforms:

- The period of the spread of the COVID-19 infection coincided with the period when the percentage of respondents who "fully agree" that the country is in the right place of political, social and economic development. In addition, almost none of the respondents "disagree"with this opinion.

- The government agreed to participate in an open dialogue with citizens and the percentage of respondents who confirmed this was about $95 \%$.

- Almost all respondents are concerned about the possible economic consequences of the COVID-19 pandemic for their families, but they take a good look at the future economic situation of the country .
1. http://review.uz/uz/jvh.

2. World Development Indicators. http://wdi.worldbank.org/table/WV.1, 2018.

3. http://xabardor.uz/xitoy-koronavirusidunyo-iqtisodiyotiga-qanday-tasirqilmoqda.

4. O‘zbekiston Respublikasi Prezidenti Administratsiyasi huzuridagi lqtisodiy tadqiqotlar va islohotlar markazining jamoatchilik bilan aloqalar xizmati, https://review.uz/oz/9xm\#.

5. https://www.worldbank.org/en/country/u zbekistan/brief/l2cu

\section{REFERENCES}

